DOI: $10.18778 / 2084-140 X .10 .26$

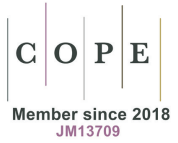

\title{
Пламен Павлов, Забравеното Средновековие [Plamen Pavlov, The Forgotten Middle Ages], Българска История, София 2019, pp. 303.
}

$\mathrm{L}$ ast year, Plamen Pavlov - an outstanding Bulgarian researcher and promoter of knowledge about medieval (but not only) Bulgaria $^{1}$, for years associated with the University of Saints Cyril and Methodius in Veliko Tărnovo - published a book entitled Забравеното Средновековие [The Forgotten Middle Ages], the purpose of which was to familiarize a wide range of readers with less known issues related to the Bulgarian Middle Ages. The book consists of twenty-five texts. Some of them had already been published (but have been reviewed and supplemented by the author); others have "premiered" in the discussed book.

The Forgotten Middle Ages opens with the text Кубер и „двойното начало” на средно-

\footnotetext{
${ }^{1} \mathrm{P}$. Pavlov is the author of numerous publications on the Bulgarian Middle Ages, but not only. The bibliography of his works includes several hundred items; the list of his works published up to 2019 - С. ГЕоргиЕв, Н. Хрисимов, Списък на трудовете на Професор доктор Пламен Христов Павлов, [in:] Владетел, държава и иғрква на Балканите през Средновековието. Сборник в чест на 60-годишнината на проф. д-р Пламен Павлов, р. 1, еd. Н. Кьнев, Н. Хрисимов, Велико Търново 2020 [= АММТ, 1], p. 26-80. For instance: П. ПАвлов, Княз Пресиан II (последният владетел на Първото българско ияарство и претендент за византийския престол), Стара Загора 1993; IDEм, Залезът на Първото българско иарство (1015-1018), София 1999; IDEM, Българското средновековие. Познанто и непознато. Страници от политическата и културната история на България, VII-XV век, Велико Търново 2008; IDEM, Векът на изар Самуил, София 2014; IDEM, И. ТютюнджиЕв, Османските завоевания u „Дьржавата на Духа”, Велико Търново 2017.
}

вековна България [Kuber and the "double beginning" of medieval Bulgaria] (p. 11-19). It is devoted to the role of the so-called Kuber's Bulgaria (located in Macedonia), little known to the average reader, in the process of establishing the medieval Bulgarian state.

The protagonist of the next text Кан Тервел и неговите съвременници [Khan Tervel and his contemporaries] (p. 20-28) is Khan Tervel (700-720), successor of Asparuh (the founder of Danubian Bulgaria). The author also reflects on the rulers (of Byzantium, the Arabs, Khazars) as well as leaders with whom Tervel came into contact (especially during the Arabs' siege of Constantinople in the years 717-718). Pavlov claims that Tervel deserves a prominent place in the pantheon of European heroes who defended Europe against the Arabs.

In the text Кгрвавото лято на 811 година [The Bloody Summer of 811] (p. 29-37), Pavlov outlines the achievements and figure of Khan Krum (802/803-814), paying particular attention to his victory in 811 over the Byzantine armed forces, commanded by Emperor Nicephorus I. He concludes by saying that due to his achievements and role in the history of medieval Bulgaria, Krum should bear the nickname "The Great".

The article Българската власт отвъд Тимок и Морава (краят на VII - средата на IX в.) [The Bulgarian power beyond the Timok and Morava (the late $7^{\text {th }}$ - the mid-9 $9^{\text {th }}$ centuries)] (p. 38-48) was devoted to the history of the Bulgarian presence on Serbian lands in the period between the late $7^{\text {th }}$ and the mid- $9^{\text {th }}$ centuries. 
The next text, mysteriously entitled "Осмият" от седмочислениците [The "eighth" of the Seven Holy Men] (p. 49-58) covers the activities of Boris-Michael, who decided to introduce Bulgaria into the circle of Christian states. According to Pavlov, his achievements in the religious sphere, including the support for the disciples of Saints Constantine-Cyril and Methodius, justifies calling him the eighth of the Seven Holy Men (this term is used in reference to the disciples of the Solun Brothers).

The text Цар Симеон Велики и „историята на древните" [Tsar Simeon the Great and the "ancient history"] (p. 59-69) is devoted to the political ideology promoted by Tsar Simeon I the Great, according to which the Bulgarians become "the chosen people" and Simeon - the new Moses.

In the article Последните дни на изар Самуил [The final days of Tsar Samuel] (p. 70-78), Pavlov analyzes the source material on the circumstances of the death of Tsar Samuel. He indicates, e.g. that since Samuel was a prominent figure across the globe at that time, and his death was recorded in sources of various provenance. The Bulgarian scholar concludes his arguments with a postulate that the remains of Samuel - discovered in Prespa (in the Church of St. Achilles) by the Greek scholar Nikolaos K. Moutzopoulos, and not transferred to Bulgaria - should be placed in the Hagia Sophia Church in Sofia-Serdica, which was probably his birthplace.

Владимировият крбст - неизвестна реликва от времето на изар Самуил и неговите наследници [Vladimir's cross - the unknown relic from the time of Tsar Samuel and his successors] (p. 79-84) concerns the fate of the cross, which John Vladimir (the prince of Duklja) was said to have received from the Bulgarian ruler, and which he yielded when he died in Prespa at the order of Tsar Ivan Vladislav. Currently, this cross is believed to be in the hands of the Andrović family and used during religious ceremonies in one of the churches near Bar. Due to the importance of this relic, Pavlov calls for further research by Bulgarian and Montenegrin scholars to verify whether the cross owned by the Androvićs is indeed Vladimir's cross.
In order to present Plamen Pavlov's scholarly argumentation, we will devote a little more space to characterize the next two, important texts. The first of them: Пресиан II - последният владетел на Пгрвото българско изарство (1018 2.) [Presian II - the last ruler of the First Bulgarian Empire (1018)] (p. 85-97) is a summary of completely novel research by Plamen Pavlov, related to the collapse of the First Bulgarian State ${ }^{2}$. It was dedicated to the last ruler of this political creation (this fact has been proven by Pavlov), namely Presian II (1018), the eldest son of Tsar Ivan Vladislav (1015-1018), so far considered to be the last ruler in early medieval Bulgaria. Aware of the scarce and succinct references to Presian in the sources of the era, the Bulgarian scholar convincingly reconstructs the political life of this ruler. He points to the significance of the name he received from his father, which is a reference to one of the earlier predecessors on the Bulgarian throne, from the period before the official Christianization of Bulgaria, that is, Khan Presian (836-852). Pavlov sees this as evidence of dynastic ties between the Komitopouloi and the family of Krum himself, and perhaps also a suggestion on the part of Ivan Vladislav at the seniority of the Aaron family, from which he came, over that of Samuel. In addition, the reference to Khan Presian, during whose time the borders of the Bulgarian state reached the Adriatic Sea and the vicinity of Thessalonica, could have had a symbolic meaning in the context of the struggle with Byzantium in the second decade of the $11^{\text {th }}$ century. The author points to the moment when the Byzantine-Bulgarian war ended, which is evidenced by the actions of the Byzantines, as an important element of proving the tsarist title of Presian II. The military stand, from which Emperor Basil II (976-1025) himself reportedly spoke to his victorious soldiers and defeated enemies (a custom cultivated since the times of the Roman Republic), was ordered by the basileus to be brought out only after Presian had surrendered. The latter, along with his younger brothers, Alusian and Aaron, had resisted the imperial army by taking refuge on

${ }^{2}$ П. ПАвлов, Княз Пресиан II...; IDEM, Залезбт... 
Mount Tomor. The defeated Bulgarian tsar received the high title of a magister ${ }^{3}$. Additionally, he and the rest of the ruling family and representatives of the Bulgarian nobility were included in the Byzantine aristocracy. In the past, another Bulgarian ruler, Boris II (969-971), had been dethroned and treated in the same way by Emperor John I Tzymiskes (969-976). The hypothesis of the Bulgarian historian regarding Presian's tsarism is also confirmed by one of the miniatures in the so-called Venetian Psalter of Basil II, in which the Bulgarian was depicted dressed in the robes similar to those worn by the basileus and is clearly the most important figure among the eight representatives of the Bulgarian aristocracy displayed there. Pavlov follows Presian's further career, now as a Byzantine magister and strategist in Asia Minor, during which he twice participated in the coups against the reign of Constantine VIII (1025-1028) in 1026, and Roman III (1028-1034) in 1030 (according to Pavlov, and contrary to the popular belief that it happened in 1029). Importantly, the researcher opts for the interpretation in which the driving force behind Presian's actions was not the personal desire to seize the Byzantine throne as part of internal struggles within the East Roman aristocracy (as viewed, for instance, by a scholar of the same renown, Vassil N. Zlatarski), but the wish to restore Bulgarian statehood, the liberation of the Bulgarians from the Byzantine yoke, or the creation of a common Byzantine-Slavic state. This view is in line with a tendency noticeable in more recent studies by Bulgarian historians (Pavlov was the one who set its course) on the rebellions of the Bulgarian nobility within the Byzantine Empire ${ }^{4}$.

\footnotetext{
${ }^{3}$ On the system of offices and titles in the Byzantine state hierarchy at the time, see, e.g. N. KANEv, Byzantine Rank Hierarchy in the $9^{\text {th }}-11^{\text {th }}$ Centuries, SCer 8, 2018, p. 153-165; IDEM, Emperor Basil II and the Awarding of Byzantine Honorific Titles to Bulgarians in the Course of the Conquest of Bulgaria (976-1018), SCer 9, 2019, p. 455-473.

${ }^{4}$ Cf. е.g. Р.С. ЙордАнов, Заговоргт на Елемаг и Гавра през 1019 г., [in:] Хиляда години от битката при Беласииа и от смғртта на цар Самуил (1014-2014), ed. В. ГюзЕлЕв, Г.Н. Николов, София 2015, p. 122-128.
}

The final accent of his deliberations concerns the death of the former Bulgarian tsar. Pavlov supports the version according to which the Bulgarian spent the last years of his life in Hungary (a view based on a mention of his name in an inscription discovered during archaeological research of the medieval rotunda in the city of Michalovce, Slovakia).

The second of the more extensively presented texts, Загадката Петгр Делян [The mysterious Peter Delyan] (p. 98-105) was devoted to the leader of the greatest Bulgarian uprising against Byzantine power in 1040-1041. Pavlov follows the fate of the titular Peter from the moment he appeared in Byzantine sources until the final collapse of his endeavor, emphasizing the lack of knowledge about the actual origin and portrait of this representative of the Bulgarian aristocracy. The researcher presents Peter Delyan as a charismatic man, skilled organizer, and expert in military matters, although, according to the author, not a real descendant of the Komitopouloi family - the son of Gabriel Radomir and the grandson of Tsar Samuel. There are two new points to note in the reflections of the Bulgarian historian: a) the assumption (as stated by the archaeologist Ivan Petrinski) that Peter Delyan established a temporary capital of a renewed Bulgarian state - restored, at least, from a Bulgarian perspective - in Ostrovo (today the city of Arnissa in Greece) near Thessalonica, the second most important Byzantine metropolis in the Balkans, after the capital Constantinople; b) an indication that the nickname Delyan, which the Byzantine author Michael Psellos had derived from the Greek dolianos, meaning "crafty", "cunning", "deceptive", actually comes from the Old Bulgarian verb odoleti, meaning "I win", so the leader of the uprising would have the nickname corresponding to the Latin Victor - "The Winner".

The next two texts Бунтвт на граничаря Нестор [The rebellion of the border guard Nestor] (р. 105-113) and Травъл и въстанието на павликяните (1084-1086) [Traulos and the Paulician Uprising (1084-1086)] (p. 114-123) discuss the leaders of the rebellions that broke out in the Bulgarian lands in the 1070s and 1080s. They were led by the people who had 
been in the Byzantine service before the revolt. Despite their Bulgarian origin, they did not choose to proclaim themselves as the tsars of Bulgaria and take up the fight to restore Bulgarian statehood.

In the text Методите на „психологическата война" във въстанието на Петьр и Асен [The methods of psychological warfare in the Uprising of Peter and Asen] (p. 124-134), Pavlov examines the methods applied by TheodorePeter and Asen during the uprising against the Byzantines ${ }^{5}$. The author illustrates that in order to achieve their goals, they were able to skillfully use the social sentiments, national and psychological features, ideas, aspirations and fears of the medieval Bulgarians.

In the text Квм психологическия портрет на иар Калоян (1197-1207) и неговата политика [On the psychological portrait of Tsar Kaloyan and his politics] (p. 135-145), Pavlov characterizes Kaloyan as having relatively extensive knowledge of Bulgarian history and knowledge of political partners, opponents and foes. He applied this knowledge expertly to implement his ambitious, imperial policies.

The next text Военните съюзници на Второто българско иарство [The military allies of the Second Bulgarian Empire] (p. 146-163) presents the allies sought out by the rulers of the Second Bulgarian Empire. P. Pavlov elaborates in particular on the cooperation between the Bulgarians and the Cumans.

In the article Иван Асен II „в странатана pycume" [Ivan Asen II "in the land of the Rus'"] (p. 164-174), the author challenges the view that Ivan Asen II (and his younger brother Alexander) had been staying in the Principality of Galicia before taking up the fight for the Bulgarian throne against Boril. According to the researcher from Tărnovo, the sons of Asen I had stayed in Kiev.

\footnotetext{
${ }^{5}$ See also: К. МАринов, Бунтовният Хемус. Масивът като база за нападения и убежище по време на първите Асеневци, Епо 23.2, 2015, р. 330-347; IDEм, Новият Завет и византийската пропаганда. Още веднъж за Никита Хониат и българското освободително движение, [in:] Великите Асеневии, ed. П. ПАвЛов, Н. Кънев, Н. ХРИСимов, Велико Търново 2016, p. 70-83.
}

The text "Латинските” влияния в средновековна България ["Latin" influences in medieval Bulgaria] (p. 175-185) illustrates Latin influences in Bulgaria, both political, cultural, and religious.

The section „Снощи татари минаха...” ["Last night the Tatars marched through..."] (p. 186-197) deals with the issue of Tatar influence (under Nogai and Chaka) in Bulgaria and the efforts to combat them (at the end of the $13^{\text {th }}$ century).

In the article „Царю Александре, твоят митничар да взема според закона...” [“Tsar Aleksander, let your customs officer collect according to the law..."] (p. 198-205), Pavlov, opening with the fragment of a gramota of the Wallachian voivode Radu I, quoted in the title, examines the issue of Bulgarian influence in $14^{\text {th }}$-century Wallachia ${ }^{6}$.

The text Многото „Бблгарии” през XIV век [Multiple "Bulgarias" in the $14^{\text {th }}$ century] (p. 206210) characterizes the decentralization process of the Bulgarian state in the $14^{\text {th }}$ century, indicating that before the Turkish conquest, there had been several Bulgarian state centers with capitals in Veliko Tărnovo, Vidin, Kaliakria, Prilep, Velbăzhd (today: Kyustendil) as well as so-called Byzantine Bulgaria with its capital in Mesembria (today: Nesebăr).

In the article Българите и турската експанзия в Мала Азия (краят на XIII - средата на XIV в.) [Bulgarians and the Turkish expansion in Asia Minor (the late $13^{\text {th }}$ - first half of the $14^{\text {th }}$ centuries)] (p. 211-230), Plamen Pavlov discusses the participation of the Bulgarians in the battles against the Ottoman Turks at the beginning of their expansion against the Byzantines. He formulates the view that прадедите на българите от Беломорска Тракия [...] са между пгрвите и най-смели бории срещу турската експанзия още във времето на нейното зараждане в Мала Азия [the ancestors of the

${ }^{6} \mathrm{Cf}$. also the most recent works devoted to this subject - Т. Попов, Българската държавна традиция във Влашката низина, Молдова и Бесарабия от края на XII до края на XV в., София 2017; IDEм, Българското влияние върху държавните институции на Влахия и Молдова (XIV - началото на XVIII в.), София 2018. 
Bulgarians from Aegean Thrace were among the first and boldest fighters against the Turkish expansion at its dawn in Asia Minor].

In the article Константин и Фружин: залезгт на средновековната българска държавност (Constantine and Fružin: the decline of medieval Bulgarian statehood] (p. 231-238), the author presents interesting reflections on the functioning of some form of Bulgarian statehood (Vidin Bulgaria) after 1397, as well as the fates of Constantine II, son of Ivan Sratsimir, the ruler of Vidin, and Fružin, son of Tsar Ivan Šišman, the ruler of Tărnovo ${ }^{7}$.

The text Патриарх Йосиф II и неговите ученици [Patriarch Joseph II and his students] (p. 239-248) focuses on the activities of the Constantinople Patriarch Joseph II (1416-1439), Ivan Shishman's son out of wedlock. The author also outlines the profiles of his disciples (Bulgarians), including Ignatius, the metropolitan of Tărnovo, the Moldavian metropolitans Damian (1437-1447) and Teoctist (1453-1478), or Cardinal Isidor (who, according to Pavlov, had Bulgarian roots).

In the article Българи, начело на Печката naтриаршия [Bulgarians at the helm of the patriarchy in Pécs] (p. 249-264), the scholar lays out the profiles of the clergymen who were at the head of the Serbian patriarchy in Pécs (both in the first and the second period of its existence) and were Bulgarian by origin.

The last text "Пврвите дами” на българското средновековие ["First Ladies" of the Bulgarian Middle Ages] (p. 265-282) reviews the medieval Bulgarian female rulers and Bulgarian women on the thrones of other countries. The author notes the scarcity of source data on women in medieval Bulgaria.

The book is supplemented with an introduction entitled Често очевидното е незабележимо (встьпителни думи) [Often the obvious goes unnoticed (Foreword)] (p. 6-9) and the bibliography (p. 284-303).

The above-discussed book provides a good insight into the research interests of Plamen

\footnotetext{
${ }^{7}$ In Polish literature, these issues are presented in: M.J. Leszka, Kwestia tzw. Powstania Konstantyna i Frużyna $w$ bułgarskiej literaturze naukowej, BP.AS 21, 2014, p. 5-12.
}

Pavlov and testifies to the freshness of his view on numerous aspects of the history of medieval Bulgaria. Although the book is intended for a wide range of readers of historical literature, it is also interesting and inspiring for scholars studying the history of Bulgarians and their country in the Middle Ages.

\section{BibLIOgRAPHY}

Georgiev S., Hrissimov N., Spisăk na trudovete na Profesor doktor Plamen Hristov Pavlov, [in:] Vladetel, dăržava i cărkva na Balkanite prez Srednovekovieto. Sbornik $v$ čest na 60-godišninata na prof. d-r Plamen Pavlov, p. 1, ed. N. Kanev, N. Hrisimov, Veliko Tărnovo 2020 [= Acta Mediaevalis Magnae Tarnoviae, 1], p. 26-80.

JoRdanov R.S., Zogovorăt na Elemag i Gavra prez 1019 g., [in:] Hiljada godini ot bitkata pri Belasica $i$ ot smărtta na car Samuil (1014-2014), ed. V. GJuzelev, G.N. Nikolov, Sofija 2015, p. 122-128.

KANEv N., Byzantine Rank Hierarchy in the $9^{\text {th }}-11^{\text {th }}$ Centuries, "Studia Ceranea. Journal of the Waldemar Ceran Research Center for the History and Culture of the Mediterranean Area and South-Eastern Europe" 8, 2018, p. 153-165, https://doi.org/ 10.18778/2084-140X.08.09

KAnev N., Emperor Basil II and the Awarding of Byzantine Honorific Titles to Bulgarians in the Course of the Conquest of Bulgaria (976-1018), "Studia Ceranea. Journal of the Waldemar Ceran Research Center for the History and Culture of the Mediterranean Area and South-Eastern Europe" 9, 2019, p. 455-473, https://doi.org/10.18778/2084-140X.09.24

Leszka M.J., Kwestia tzw. Powstania Konstantyna i Frużyna $w$ bułgarskiej literaturze naukowej, "Balcanica Posnaniensia. Acta et studia” 21, 2014, p. 5-12, https://doi.org/10.14746/bp.2014.21.1

Marinow K., Buntovnijat Hemus. Masivăt kato baza za napadenija i ubežište po vreme na părvite Asenevci, “Епохи" / "Epohi” 23.2, 2015, p. 330-347.

MARINOw K., Novijat Zavet $i$ vizantijskata propaganda. Ošte vednăž za Nikita Honiat i bălgarskoto osvoboditelno dviženie, [in:] Velikite Asenevci, ed. P. PAVLov, N. Kanev, N. Hrissimov, Veliko Tărnovo 2016 , p. 70-83. 
Pavlov P., Bălgarskoto srednovekovie. Poznato i nepoznato. Stranici ot političeskata $i$ kulturnata istorija na Bălgarija, VII-XV vek, Veliko Tărnovo 2008.

Pavlov P., Knjaz Presian II (poslednijat vladetel na Părvoto bălgarsko carstvo i pretendent za vizantijskija prestol), Stara Zagora 1993.

Pavlov P., Vekăt na car Samuil, Sofija 2014.

PAvlov P., Zalezăt na Părvoto bălgarsko carstvo (10151018), Sofija 1999.

Pavlov P., Tuutjundžıev I., Osmanskite zavoevanija i „Dăržavata na Duha”, Veliko Tărnovo 2017.

Popov T., Bălgarskata dăržavna tradicija văv Vlaškata nizina, Moldova i Besarsbija ot kraja na XII do kraja na XV v., Sofija 2017.
Popov T., Bălgarskoto vlijanie vărhu dăržavnite institucii na Vlahija i Moldova (XIV - načaloto na XVIII v.), Sofija 2018.

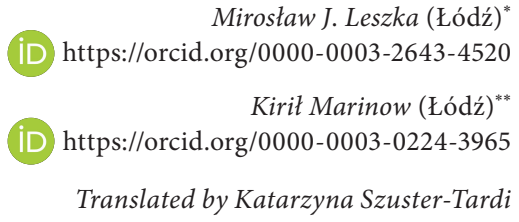

${ }^{*}$ University of Lodz, Faculty of Philosophy and History, Department of Byzantine History

${ }^{* *}$ University of Lodz, Faculty of Philosophy and History, Department of Byzantine History 